\title{
Morsrollen er \\ utfordrende for kvinner med en revmatisk sykdom
}

Mødre med artrittsykdom $\varnothing$ nsker veiledning om amming, medisinsk behandling og hvordan de kan håndtere rollen som småbarnsmor.

\section{Kjersti Grønning}

Professor og fagutviklingssykepleier

Institutt for samfunnsmedisin og sykepleie, Norges teknisk-naturvitenskapelige universitet og St. Olavs hospital

\section{Oda Sletten}

Sykepleier

Vaksinasjons- og smittevernkontoret, Trondheim kommune

\section{Karina Salte}

Sykepleier

Bemanningssenteret, St. Olavs hospital

\section{Hege Koksvik Sourza Svean}

\section{Seksjonsleder}

Nasjonal kompetansetjeneste for svangerskap og revmatiske sykdommer, St. Olavs hospital 
Småbarnsmødre med en revmatisk sykdom må håndtere sykdommen og de begrensningene den kan medføre, i tillegg til å ivareta barnets behov. I slike situasjoner er sykepleiere viktige samarbeidspartnere som kan tilby tilpasset informasjon og veiledning. Målet med veiledningen er å støtte kvinnene, slik at de mestrer rollen som småbarnsmor på en best mulig måte.

Personer som lever med en kronisk inflammatorisk artrittsykdom, slik som revmatoid artritt (RA), psoriasisartritt (PsA), juvenil idiopatisk artritt (JIA) eller spondyloartritt (SpA), har mange likhetstrekk når det gjelder plager og symptomer (1). RA er den vanligste av disse sykdommene, og kvinner rammes tre-fire ganger oftere enn menn.

De vanligste symptomene ved inflammatoriske artrittsykdommer er varierende grad av smerter, hovne ledd, stivhet, utmattelse og nedsatt funksjon. Sykdommene krever ofte medikamentell behandling med sykdomsmodifiserende antirevmatiske legemidler.

Både de yrkesetiske retningslinjene for sykepleiere (2) og de europeiske retningslinjene for sykepleiere innen revmatologi (3) legger vekt på at pasientene skal få tilstrekkelig og tilpasset informasjon, slik at de mestrer konsekvensene av sykdommen på en best mulig måte.

Pasienter med en inflammatorisk artrittsykdom uttrykker at de har behov for generell informasjon om diagnosen, prognose, graviditet, medikamentell behandling, trening og fysioterapi, sosial støtte, funksjonsnedsettelser, smerte, optimalisering av funksjon og ytelse i hverdagsaktiviteter, psykososial omsorg, selvhjelp og hvordan de kan mestre konsekvensene av sykdommen (4).

\section{Sykdommen kan blusse opp etter fødsel}


Når kvinner med en inflammatorisk artrittsykdom blir gravide, får de tilbud om oppfølging i tråd med veilederen om svangerskap og revmatiske sykdommer (5). Heldigvis er det mange kvinner med en inflammatorisk artrittsykdom som opplever å bli bedre av sykdommen under svangerskapet.

Etter fødselen opplever imidlertid en god del at sykdomsaktiviteten $\varnothing$ ker (6-8), og det kan være behov for oppstart av medikamentell behandling igjen. De fleste medikamentene som brukes til å behandle inflammatoriske artrittsykdommer, er forenlige med amming, men ikke alle $(9,10)$.

\section{Færre mødre med revmatisk sykdom ammer}

Ifølge Verdens helseorganisasjon er amming en av de mest effektive måtene å sikre god barnehelse på. Det anbefales å fullamme spedbarnet frem til det er seks måneder gammelt, for deretter å supplere med annen trygg mat frem til barnet er to år. Spedbarnet får all den energien, næringen og antistoffene det trenger gjennom brystmelk, som i tillegg er helt trygt og rent.

Selv om amming har helsefordeler for både mor og barn, viser forskning at det er færre kvinner med inflammatoriske artrittsykdommer som ammer, sammenliknet med kvinner fra befolkningen ellers (11). Kvinner med en inflammatorisk artrittsykdom avslutter også ammingen tidligere enn friske kvinner. Det er derfor viktig at disse kvinnene får informasjon, støtte og veiledning i forbindelse med medisinbruk, medisintoksisitet og amming (12).

\section{«Noen småbarnsmødre med en inflammatorisk artrittsykdom opplever seg selv som 'mislykkede' i morsrollen.»}


Kvinner med en revmatisk sykdom som har små barn, opplever i tillegg flere utfordringer i rollen som småbarnsmor. Utfordringene er relatert til å bære barna, til å leke med barna og til å innfri egne og andres forventninger til rollen som mor. Noen småbarnsmødre med en inflammatorisk artrittsykdom opplever seg selv som «mislykkede» i morsrollen fordi de ikke er i stand til å oppfylle rollen slik de hadde $\emptyset$ nsket det (13).

Vi ønsket derfor å utforske hvilke utfordringer småbarnsmødre med en revmatisk sykdom i Norge har. Denne artikkelen bygger på en studie vi utførte i 2019, hvor vi spurte småbarnsmødre med en revmatisk sykdom om det var noe de syntes har vært problematisk om det å være mor og samtidig ha en revmatisk sykdom.

\section{Metode og analyse}

Dataene i denne studien ble samlet inn i forbindelse med et nasjonalt forskningsprosjekt om helserelatert livskvalitet for småbarnsmødre med inflammatorisk artrittsykdom. Prosjektet ble gjennomført av Nasjonal kompetansetjeneste for svangerskap og revmatiske sykdommer (NKSR) ved St. Olavs hospital i 2019. Deltakerne i unders $\varnothing$ kelsen ble rekruttert fra RevNatus, et landsdekkende kvalitetsregister for svangerskap og revmatiske sykdommer (14).

I tillegg til spørsmålene om helserelatert livskvalitet fikk deltakerne anledning til å bruke egne ord for å svare på ett åpent spørsmål: «Er det noe spesielt du synes har vært problematisk i forhold til det å være mor og samtidig ha en revmatisk sykdom?»

Deltakerne kunne skrive så lite eller så mye de ønsket. Analysen av fritekstsvarene er inspirert av innholdsanalyse (15), som innebærer først å danne seg en helhetsforståelse, for deretter å sortere teksten $\mathrm{i}$ hovedtema og undertemaer. 


\section{Etiske betraktninger}

Prosjektet er godkjent av Regionale komiteer for medisinsk og helsefaglig forskningsetikk (2019/817/REK sør-øst C). Deltakerne fikk tilsendt et informasjonsskriv om prosjektets hensikt, og de samtykket skriftlig til å være med i studien.

\section{Resultater}

Totalt 230 mødre i alderen 22 til 44 år deltok i unders $\varnothing$ kelsen. Av disse svarte 183 (80 prosent) på det åpne spørsmålet «Er det noe spesielt du synes har vært problematisk i forhold til det å være mor og samtidig ha en revmatisk sykdom?». Analysen av disse svarene resulterte i ett hovedtema, «den utfordrende morsrollen», og to undertemaer, «sorg og utilstrekkelighet» og «amming».

\section{Den utfordrende morsrollen}

Noen av mødrene oppga at det var ensomt å leve med diagnosen i hverdagen. De opplevde at de var litt «annerledes» mødre enn andre, fordi de var nødt til å ta hensyn til ting som andre mødre ikke trengte å tenke på. Et par av mødrene opplevde også at de ikke ble forstått når de var hos legen eller på helsestasjonen. Noen savnet også at helsevesenet tok mer tak i problemene de hadde relatert til leddgikten.

Flere av mødrene hadde forventninger til seg selv som de syntes at de ikke greide å innfri. Noen opplevde også at andre hadde forventninger til dem som de ikke greide å leve opp til. En mor skrev at hun følte at hun alltid var på etterskudd, og at det var mye hun skulle gjort som hun ikke orket.

Mange uttrykte også at det var slitsomt å leve med en sykdom som var så uforutsigbar. De gode og vonde dagene ble veldig kontrastfulle, og flere opplevde at det kunne være vanskelig for folk rundt dem å forstå hvordan de hadde det.

\section{«Mange beskrev en hverdag preget av harde prioriteringer.»}


Andre sa at sykdommen førte til at de følte at de aldri strakk til. De var ofte nødt til å si nei til ting som barna hadde lyst til å være med på. Dette forklarte de med at de hadde mye smerter, var trette eller følte seg helt utmattet. En av respondentene beskrev det slik:

«Det kreves mye dugnadsjobber og at man stiller opp for de ulike arrangement. Det er vanskelig å innfri når man har en hverdag preget av mye smerter og utmattelse. Man møter ofte lite forståelse fra andre, som ikke klarer å forstå din situasjon. Mange tror det bare er å ta seg sammen, fordi du ser så frisk ut på utsiden.»

Flere oppga at smerter og lite energi gjorde at de manglet overskudd til de hverdagslige aktivitetene. Manglende overskudd innvirket i neste omgang på gleden over hverdagslige aktiviteter sammen med barna.

Mange beskrev en hverdag preget av harde prioriteringer. A kombinere et yrkesaktivt liv med små barn opplevdes som krevende, og flere oppga at de hadde dårlig samvittighet. En av deltakerne beskrev det på denne måten:

«A kombinere å være mor, sykdom og arbeid er vanskelig. Man vil være en god mor, men klarer det ikke alltid. Det er vanskelig å prioritere barna.»

\section{Sorg og utilstrekkelighet}

Mange av småbarnsmødrene kjente på en stor sorg fordi sykdommen gjorde at livet ikke ble slik de hadde planlagt. En av kvinnene beskrev følelsen av utmattelse som en av de største utfordringene i hverdagen, som begrenset henne på mange måter. Flere skrev at det var både vondt og vanskelig ikke å klare å ta seg av sitt eget barn i den grad de hadde $\emptyset$ nsket. Følgende sitat er et godt eksempel på det: 
«Sykdommen tar mye fokus og energi, som jeg heller skulle brukt på å følge opp barna mine. Det er trist å ikke klare å løfte sitt eget barn ut av senga, stelle og hjelpe til med påkledning. I oppveksten er det sårt å ikke kunne delta på aktiviteter eller følge de på turer i den grad jeg ønsker.»

Flere oppga at de manglet energi og overskudd til å gi barna den omsorgen og oppmerksomheten de syntes de fortjente. Mulighetene til barna ble redusert på grunn av mors helse, og dette opplevde de som urettferdig. Gleden over å være mor forsvant litt i sykdommen.

\section{«De hadde mye dårlig samvittighet, og det var vanskelig å akseptere situasjonen som den var.»}

Mange hadde også $\varnothing$ nsker og store ambisjoner for småbarnsperioden og alt de skulle gjøre sammen med barna. Følelsen av utilstrekkelighet meldte seg fort når de innså at de ikke klarte dette. En av kvinnene uttrykte det på denne måten:

«Mange av verdiene jeg ønsket å være i morsrollen har jeg ikke mulighet til på grunn av smerter og fatigue, som f.eks. oppleve naturen, bake og små byggeprosjekter.»

Noen av mødrene ga også uttrykk for at de ikke greide å være de mødrene de ønsket. De hadde mye dårlig samvittighet, og det var vanskelig å akseptere situasjonen som den var. En av deltakerne uttrykte det slik:

«Man har forventninger til å være der for barna hele tiden, men det er tøft å innse at man ikke klarer det. Hodet vil mer enn kroppen.»

En mor kjente spesielt på dårlig samvittighet for måten hun håndterte situasjoner på, spesielt når tålmodigheten var svekket på grunn av smerter og fatigue. 
Samtidig viste mødrene at de ikke ga opp, de jobbet kontinuerlig med å håndtere sykdommen på en best mulig måte, slik at den ikke skulle gå ut over barna. En av kvinnene beskrev det på denne måten:

«Er litt utfordrende mentalt å innse at man har begrensninger pga. sykdom som går ut over / vil gå ut over det å være en tilstedeværende mor. Føler at jeg svikter litt i rollen jeg selv har valgt.»

\section{Amming}

Det var flere av deltakerne som oppga at de hadde hatt utfordringer knyttet til amming og bruk av medisiner. Et tema som gikk igjen, var tidlig ammestopp grunnet smerter og behov for å begynne å ta medisiner. I tillegg opplevde flere at det var vanskelig å velge mellom å fortsette å amme og å begynne på medisiner. En av mødrene beskrev det slik:

«Jeg måtte avslutte ammingen etter fem-seks måneder på grunn av behov for å ta metotreksat mot betennelser. Det var veldig sårt, og barnet var uvillig til å ta flaske og drikke morsmelk-erstatning.» Noen av deltakerne påpekte også at de savnet veiledning og oppfølging relatert til amming og en mer konkret plan for oppstart av medikamentell behandling etter fødsel, og før ammestopp.

En av kvinnene skrev at hun under svangerskapet var veldig dårlig av sykdommen. Hun var usikker på om hun kunne bruke de biologiske legemidlene, og hvorvidt hun kunne amme eller ikke:

«Jeg synes oppfølgingen fra sykehuset i denne perioden har vært dårlig. Jeg har vært på kontroller, det er ikke mangel på det, men det er vanskelig å få hjelp / bli hørt / tatt på alvor / føle at de tar seg tid til å hjelpe meg med problemene mine knyttet til leddgikten. Nattamming er slitsomt da alle stillinger er vonde å ligge i.» 


\section{Diskusjon}

Hensikten med denne studien var å utforske hvilke utfordringer småbarnsm $\varnothing$ dre med revmatiske sykdommer beskriver.

Hovedfunnene viste at småbarnsmødrene opplevde morsrollen som utfordrende, de kjente på sorg og utilstrekkelighet fordi sykdommen gjorde at livet ikke ble slik de hadde planlagt. Flere fortalte om usikkerhet knyttet til amming, og flere savnet mer informasjon, veiledning og støtte.

\section{Sykepleiere kan hjelpe med å bearbeide sorg}

Rollen som småbarnsmor med revmatisk sykdom oppleves som utfordrende for en del kvinner. I perioder med smerter og lite energi har de ikke like mye tålmodighet eller overskudd til å være den småbarnsmammaen de hadde $\varnothing$ nsket. Flere av kvinnene oppga at de bar på en sorg over at livet ikke ble slik de forventet.

Sorg er en kjent følelsesmessig reaksjon hos personer med en inflammatorisk artrittsykdom (16). For småbarnsmødre kan sorgen handle om at de har mistet energi og overskudd til å delta i aktiviteter sammen med barna på grunn av sykdommen.

\section{«For en del småbarnsmødre er det utfordrende å innse at de ikke greier å innfri de forventningene de hadde til morsrollen.»}

Sorgen må bearbeides, og her kan sykepleiere gjøre en forskjell. I møte med småbarnsmødrene må sykepleieren lytte til det kvinnene opplever som utfordrende, og finne ut hva de trenger hjelp til, og om det er noe som kan redusere utfordringene. Det er viktig at sykepleieren underst $\varnothing t t e r$ og styrker kvinnene, slik at de opplever sammenheng i tilværelsen. 
For småbarnsmødre med en revmatisk sykdom kan dette innebære å få hjelp og st øtte fra sykepleieren til å akseptere at de ikke ble den mammaen de hadde planlagt (13). Dette er viktig, da det for en del småbarnsmødre er utfordrende å innse at de ikke greier å innfri de forventningene de hadde til morsrollen $(13,16)$.

Det er ikke unormalt at småbarnsmødre kjenner på følelser som avmakt og tretthet fordi barnet er helt avhengig av dem. Som omsorgspersoner må de dekke alle barnets basale fysiske og emosjonelle behov.

For kvinner med en kronisk sykdom kan dette oppleves som ekstra slitsomt fordi de må håndtere sin egen sykdom i tillegg. Da er det viktig at sykepleieren trygger og støtter småbarnsmødrene, slik at de opplever å mestre rollen som mor. Kommentarer som «Jeg føler at jeg alltid er på etterskudd» illustrerer at småbarnsm ødre trenger st $\varnothing t t e$ fra sykepleieren til å mestre utfordringene som småbarnsperioden kan ha.

Sykepleieren har en viktig funksjon i å hjelpe kvinnene til å finne tryggheten og troen på at de er gode nok som de er, slik dette sitatet illustrerer: «Har følt meg ganske utilstrekkelig innimellom, men gutten er glad og fornøyd, så det har nok mest vært mine egne forventninger som har vært problemet.»

\section{Mange er usikre på amming og medisinering}

Usikkerhet knyttet til amming var et annet tema som flere av kvinnene rapporterte som utfordrende. Flere hadde opplevd $\varnothing \mathrm{kt}$ sykdomsaktivitet etter fødselen. For å dempe aktiviteten måtte de starte med medisiner igjen.

Oppstart av den medikamentelle behandlingen gjorde at noen avsluttet ammingen før barnet var seks måneder, noe som også er påvist i tidligere forskning (11). Samtidig viser forskning at mange som avsluttet ammingen, begynte med medisiner som var forenlige med amming i henhold til datidens retningslinjer (11). 


\section{«Ikke å starte medisinsk behandling kan føre til permanente leddødeleggelser.»}

Mulige årsaker til tidlig ammestopp kan være en generell frykt for å ta medisiner når man ammer, eller for lite informasjon og veiledning om hvilke medikamenter som er forenlige med amming, og hva forenlig med amming egentlig betyr. I tillegg til generelle retningslinjer for hvilke medikamenter som kan brukes ved amming, er det behov for veiledning om hva som passer best for den enkelte kvinnen i hennes situasjon.

Noen av småbarnsmødrene i denne studien opplevde det som et vanskelig dilemma å velge mellom å holde ut smertene og fortsette ammingen, eller å begynne med medisiner og stoppe ammingen. For noen handlet det ikke bare om å «holde ut smertene», for det ikke å starte medisinsk behandling kan også føre til permanente leddødeleggelser med varige funksjonelle nedsettelser (1).

Dilemmaer som å veie ammestopp og oppstart med medisiner opp mot de positive fordelene med amming kan det være utfordrende å ta stilling til på egen hånd (12). I slike situasjoner kan sykepleieren veilede kvinnene om amming, medisinsk behandling og hvordan de kan håndtere rollen som småbarnsmor med en kronisk sykdom på en best mulig måte $(3,17$, 18).

Målet med veiledningen er at kvinnene opplever at de mestrer situasjonen de er i, og at de føler seg trygge når de skal velge om de skal starte med medikamentell behandling eller ikke, og om de skal fortsette eller avslutte ammingen.

Noen får ikke oppfølgingen de trenger 
Siden de inflammatoriske leddsykdommene er uforutsigbare, spesielt når det gjelder risikoen for $\varnothing \mathrm{kt}$ sykdomsaktivitet etter fødsel (19), er det europeiske revmatologiske fagmiljøet enige om at det skal være enkelt for pasientene å komme i kontakt med en sykepleier når de har behov for støtte (3). Likevel viser det seg at noen pasienter opplever at de ikke får den oppfølgingen de trenger.

Hvis pasientene opplever at oppfølgingen ikke er tilstrekkelig, må sykepleieren finne ut hva som mangler. Sykepleieren har et ansvar for å tilby pasientene hjelp og støtte til å håndtere sykdommen gjennom hele sykdomsforløpet (3), noe som innebærer å tilby individtilpasset veiledning og støtte til å mestre rollen som småbarnsmor med revmatisk sykdom, hjelp til å bearbeide sorg over at sykdommen endret livet, og støtte når vanskelige valg skal tas.

Sykepleieren må også unders $\varnothing$ ke hvordan veiledningen og oppfølgingen best kan tilbys den enkelte kvinnen (20). Noen pasienter foretrekker veiledning ansikt til ansikt, mens andre synes det fungerer like bra med veiledning på telefon eller video (21).

\section{Styrker og svakheter ved studien}

En styrke ved denne studien er at småbarnsmødrene ble rekruttert fra det landsdekkende kvalitetsregisteret RevNatus. Alle kvinner med en inflammatorisk artrittsykdom som følges opp ved en revmatologisk enhet i forbindelse med svangerskap, inkluderes i registeret. Studien inneholder derfor et komplett utvalg av småbarnsmødre med en revmatisk sykdom i Norge.

Det åpne spørsmålet ga kvinnene mulighet til å bruke egne ord om sine opplevelser og erfaringer med å være småbarnsmor, i motsetning til å sette kryss ved ferdigformulerte svaralternativer. Kvinnenes beskrivelser kunne derfor analyseres med en kvalitativ tilnærming. 
En svakhet ved studien er at vi ikke kunne følge opp kvinnenes beskrivelser med videre spørsmål, slik man kunne gjort hvis de hadde blitt intervjuet (22).

\section{Konklusjon}

Resultatene i denne studien viser at flere småbarnsmødre opplever at rollen som småbarnsmor med en revmatisk sykdom er utfordrende. De kjente på følelser av sorg og utilstrekkelighet fordi livet med små barn ikke ble slik de hadde sett for seg, og de måtte håndtere vanskelige dilemmaer knyttet til amming og oppstart av medikamentell behandling etter fødselen. Flere savnet også mer informasjon, veiledning og støtte.

\section{Referanser}

1. Ledingham J, Snowden N, Ide Z. Diagnosis and early management of inflammatory arthritis. BMJ. 2017;358:j3248.

2. Norsk Sykepleierforbund. Yrkesetiske retningslinjer for sykepleiere: ICNs etiske regler. Oslo: Norsk Sykepleierforbund; 2019. Tilgjengelig fra: https://www.nsf.no/sykepleiefaget/yrkesetiskeretningslinjer (nedlastet 27.04.2021).

3. Bech B, Primdahl J, van Tubergen A, Voshaar M, Zangi HA, Barbosa L, et al. 2018 update of the EULAR recommendations for the role of the nurse in the management of chronic inflammatory arthritis. Ann Rheum Dis. 2020;79(1):61-8.

4. Connelly K, Segan J, Lu A, Saini M, Cicuttini FM, Chou L, et al. Patients' perceived health information needs in inflammatory arthritis: a systematic review. Semin Arthritis Rheum. 2019;48(5):900-10.

5. Nasjonal kompetansetjeneste for svangerskap og revmatiske sykdommer (NKSR). Veileder i svangerskap og revmatiske sykdommer [internett]. Trondheim: St. Olavs hospital; [oppdatert mai 2021; sitert 12.05.2021]. Tilgjengelig fra: https://www.nksr.no/ 
6. Ursin K, Lydersen S, Skomsvoll JF, Wallenius M. Disease activity during and after pregnancy in women with axial spondyloarthritis: a prospective multicentre study. Rheumatology (Oxford). 2018;57(6):1064-71.

7. Ursin K, Lydersen S, Skomsvoll JF, Wallenius M. Disease activity of juvenile idiopathic arthritis during and after pregnancy: a prospective multicenter study. $\mathrm{J}$ Rheumatol. 2018;45(2):257-65.

8. Ursin K, Lydersen S, Skomsvoll JF, Wallenius M. Psoriatic arthritis disease activity during and after pregnancy: a prospective multicenter study. Arthritis Care Res (Hoboken). 2019;71(8):1092-100.

9. Skorpen CG, Hoeltzenbein M, Tincani A, Fischer-Betz R, Elefant E, Chambers C, et al. The EULAR points to consider for use of antirheumatic drugs before pregnancy, and during pregnancy and lactation. Ann Rheum Dis. 2016;75(5):795-810.

10. Sammaritano LR, Bermas BL, Chakravarty EE, Chambers C, Clowse MEB, Lockshin MD, et al. 2020 American College of Rheumatology guideline for the management of reproductive health in rheumatic and musculoskeletal diseases. Arthritis Rheumatol. 2020;72:529-56.

11. Ince-Askan H, Hazes JM, Dolhain RJ.

Breastfeeding among women with rheumatoid arthritis compared with the general population: results from a nationwide prospective cohort study. J Rheumatol. 2019;46(9):1067-74.

12. Ackerman IN, Jordan JE, Van Doornum S, Ricardo M, Briggs AM. Understanding the information needs of women with rheumatoid arthritis concerning pregnancy, post-natal care and early parenting: a mixed-methods study. BMC Musculoskelet Disord. 2015;16:194. 
13. Feddersen H, Kristiansen TM, Andersen PT, Hørslev-Petersen K, Primdahl J. Juggling identities of rheumatoid arthritis, motherhood and paid work - a grounded theory study. Disabil Rehabil. 2019;41(13):1536-44.

14. RevNatus - et landsdekkende kvalitetsregister for svangerskap og revmatiske sykdommer. Trondheim: St. Olavs hospital. Tilgjengelig fra: https://stolav.no/avdelinger/klinikk-for-ortopedirevmatologi-og-hudsykdommer/revmatologiskavdeling/nasjonal-kompetansetjeneste-forsvangerskap-og-revmatologiske-sykdommer/revnatus (nedlastet 27.04.2021).

15. Graneheim UH, Lundman B. Qualitative content analysis in nursing research: concepts, procedures and measures to achieve trustworthiness. Nurse Educ Today. 2004;24(2):105-12.

16. Östlund G, Björk M, Thyberg I, Thyberg M, Valtersson E, Stenström B, et al. Emotions related to participation restrictions as experienced by patients with early rheumatoid arthritis: a qualitative interview study (the Swedish TIRA project). Clin Rheumatol. 2014;33(10):1403-13.

17. Dures E, Almeida C, Caesley J, Peterson A, Ambler N, Morris M, et al. Patient preferences for psychological support in inflammatory arthritis: a multicentre survey. Ann Rheum Dis. 2016;75(1):142-7.

18. van Eijk-Hustings Y, Ammerlaan J, VoorneveldNieuwenhuis H, Maat B, Veldhuizen C, Repping-Wuts H. Patients' need and expectations with regard to rheumatology nursing care: results of multicentre focus group interviews. Ann Rheum Dis. 2013;72(6):831-5. 
19. Andreoli L, Gerardi MC, Fernandes M,

Bortoluzzi A, Bellando-Randone S, Brucato A, et al. Disease activity assessment of rheumatic diseases during pregnancy: a comprehensive review of indices used in clinical studies. Autoimmun Rev. 2019;18(2):164-76.

20. Feddersen H, Kristiansen TM, Andersen PT, Hørslev-Petersen K, Primdahl J. Interactions between women with rheumatoid arthritis and nurses during outpatient consultations: a qualitative study. Musculoskeletal Care. 2019;17:363-71.

21. des Bordes JKA, Gonzalez E, Lopez-Olivo MA, Shethia M, Nayak P, Suarez-Almazor ME. Assessing information needs and use of online resources for disease self-management in patients with rheumatoid arthritis: a qualitative study. Clin Rheumatol. 2018;37(7):1791-7.

22. Kvale S, Brinkmann S, Anderssen TM, Rygge J. Det kvalitative forskningsintervju. 3. utg. Oslo: Gyldendal Akademisk; 2019. 